\title{
Type-II diabetes and pancreatic cancer: a meta-analysis of 36 studies
}

\author{
R Huxley*,', A Ansary-Moghaddam', A Berrington de González², F Barzi' and M Woodward' \\ 'The George Institute for International Health, The University of Sydney, PO Box M20I, Missenden Road, Sydney NSW 2050, Australia; ${ }^{2}$ Cancer \\ Research UK Epidemiology Unit, University of Oxford, Gibson Building, Radcliffe Infirmary, Oxford OX2 6HE, UK
}

Pancreatic cancer is the eighth major form of cancer-related death worldwide, causing 227000 deaths annually. Type-II diabetes is widely considered to be associated with pancreatic cancer, but whether this represents a causal or consequential association is unclear. We conducted a meta-analysis to examine this association. A computer-based literature search from 1966 to 2005 yielded 17 case-control and 19 cohort or nested case-control studies with information on 9220 individuals with pancreatic cancer. The age and sex-adjusted odds ratio (OR) for pancreatic cancer associated with type-II diabetes was obtained from each study. The combined summary odds ratio was 1.82 (95\% confidence interval $(95 \% \mathrm{Cl}) \quad 1.66-1.89)$, with evidence of heterogeneity across the studies ( $P=0.002$ for case-control and $P=0.05$ for cohort studies) that was explained, in part, by higher risks being reported by smaller studies and studies that reported before 2000. Individuals in whom diabetes had only recently been diagnosed ( $<4$ years) had a $50 \%$ greater risk of the malignancy compared with individuals who had diabetes for $\geqslant 5$ years (OR 2.1 vs $1.5 ; P=0.005)$. These results support a modest causal association between type-II diabetes and pancreatic cancer.

British Journal of Cancer (2005) 92, 2076-2083. doi:I0.I038/sj.bjc.66026I9 www.bjcancer.com

Published online 10 May 2005

(c) 2005 Cancer Research UK

Keywords: pancreatic cancer; type-II diabetes; meta-analysis

Although cancer of the pancreas accounts for only $3 \%$ of all cancers worldwide (Parkin et al, 2002), its poor prognosis makes it the eighth major form of cancer-related death worldwide, causing more than 220000 deaths annually. Apart from cigarette smoking, which has been estimated to cause about $30 \%$ of pancreatic cancers (Doll and Peto, 1976; Baghurst et al, 1991), relatively little is known about the other chief determinants of the disease, although other lifestyle factors have been implicated, including obesity (Berrington de Gonzalez et al, 2003) and type-II diabetes (Everhart and Wright, 1995).

As type-II diabetes frequently occurs with pancreatic cancer, it is considered by many to be an important risk factor for the malignancy. A meta-analysis of 20 studies conducted a decade ago estimated that individuals with diabetes have a two-fold greater relative risk (RR) of pancreatic cancer compared with individuals without diabetes (Everhart and Wright, 1995). However, there is also good evidence that pancreatic cancer is causally linked to the onset of diabetes (Wang et al, 2003) and is possibly associated with an abnormality of islet cell function.

A large number of new studies have since published on the association between type-II diabetes and pancreatic cancer. Therefore, the purpose of the current study was to update the earlier meta-analysis to provide the most reliable information on the size of the association, and to explore any underlying sources of heterogeneity, including variations in the strength of the relationship with duration of diabetes.

*Correspondence: Dr R Huxley; E-mail: rhuxley@thegeorgeinstitute.org Received 7 March 2005; revised 4 April 2005; accepted 6 April 2005; published online 10 May 2005

\section{MATERIALS AND METHODS}

\section{Data sources}

Relevant studies were identified through EMBASE, PUBMED and MEDLINE using a combined text word and MESH heading search strategy of pancreatic cancer (pancreas, tumour, malignancy) and type-II diabetes (NIDDM, diabetes, adult-onset diabetes). References from identified studies, as well as from the previous review, were also scanned to identify any other relevant studies.

\section{Study selection and data synthesis}

Studies were included in this systematic review if they had published quantitative estimates and standard errors, or confidence limits, of the association between type-II diabetes and pancreatic cancer by January 2005. Studies were excluded if they provided only an estimate of effect, with no means by which to calculate the standard error, or if the estimates were not adjusted by age. The variance of the log odds ratio (OR) from each study was calculated by converting the $95 \%$ confidence interval (CI) to its natural logarithm by taking the width of the $\mathrm{CI}$ and dividing by 3.92. If the variance was unavailable, $P$-values were used to estimate the CI. Some studies provided more than one OR according to the duration of diabetes before being diagnosed with pancreatic cancer. To maintain consistency across studies, the ORs for individuals diagnosed with diabetes $>1$ year prior to the diagnosis of pancreatic cancer were extracted and combined. Summary estimates were obtained separately for case-control and cohort studies by means of a 'random effects' approach and studies 
were weighted according to an estimate of its 'statistical size' defined as the inverse of the variance of the log OR (Woodward, 2005). In addition, studies that reported separate ORs for mutually exclusive categories of duration since diabetes was diagnosed (e.g. 1-4 years, 5-9 years, $>10$ years) were pooled separately to examine how the strength of the association varied with duration of diabetes. Possible sources of heterogeneity were investigated by comparing the results for studies combined with respect to particular characteristics (e.g. sex, method of diagnosis of diabetes). All analyses were performed using STATA, version 8.

\section{RESULTS}

A total of 17 case-control and 19 cohort or nested case-control studies with information on a total of 9220 individuals with pancreatic cancer had published estimates of the association between diabetes and the malignancy. Six additional studies were excluded from this review; one study had published the standardised mortality ratio only (Kessler, 1970), and the remaining five studies contained duplicate information (La Vecchia et al, 1990; Davey Smith et al, 1992; Calle et al, 1998; Silverman et al, 1999; La Coughlin et al, 2000). The summary characteristics of included studies are shown in Tables 1 and 2. The majority of the study populations were from either North America ( $n=16)$ or Europe $(n=14)$ with the remaining five studies from either Australasia or South America. With the exception of one study that had recorded diagnosis of diabetes by proxy, diagnosis of diabetes was either through self-report, an oral glucosetolerance test, medical records or a combination of these three methods.

The pooled OR for case-control studies was 1.94 (95\% CI 1.53 2.46) (Figure 1), this being nonsignificantly higher than the summary estimate from cohort studies: 1.73 (1.59-1.88; Figure 2) $(P$ for heterogeneity $=0.37)$. The combined estimate from all studies was 1.82 (95\% CI 1.66-1.99). There was some evidence of

Table I Case-control studies of diabetes and pancreatic cancer

\begin{tabular}{|c|c|c|c|c|c|c|c|c|c|c|}
\hline \multirow[b]{2}{*}{$\begin{array}{l}\text { First author and } \\
\text { year }\end{array}$} & \multicolumn{2}{|r|}{ PC cases } & \multicolumn{2}{|r|}{ Controls } & \multicolumn{2}{|c|}{ Diabetes } & \multirow[b]{2}{*}{$\begin{array}{l}\% \text { PC } \\
\text { cases }\end{array}$} & \multirow[b]{2}{*}{$\begin{array}{l}\text { Level of } \\
\text { adjustment }\end{array}$} & \multirow[b]{2}{*}{$\begin{array}{l}\text { Relative } \\
\text { risk }\end{array}$} & \multirow[b]{2}{*}{$95 \% \mathrm{Cl}$} \\
\hline & No. & Source & No. & Source & $\begin{array}{l}\text { Source } \\
\text { diagnosis }\end{array}$ & $\begin{array}{l}\text { Duration } \\
\text { (years) }\end{array}$ & & & & \\
\hline \multirow[t]{2}{*}{ Cuzick, 1989} & 216 & $\begin{array}{l}\text { Newly diagnosed } \\
\text { patients, England }\end{array}$ & 279 & Hospital patients & $\mathrm{SR}, \mathrm{MR}$ & $>1$ & $6.0 \mathrm{M}$ & Age, sex & 2.59 & $0.63-16.1$ \\
\hline & & & & & & & $2.0 \mathrm{~F}$ & & 6.64 & $1.33-65.2$ \\
\hline \multirow[t]{2}{*}{ Wynder, 1973} & 142 & Patients, US & 142 & Hospital patients & $\mathrm{SR}$ & $>2$ & $5.0 \mathrm{M}$ & $\begin{array}{l}\text { Age, sex, race, } \\
\text { hospital }\end{array}$ & 1.00 & $0.31-3.12$ \\
\hline & & & & & & & 16.7 F & & 7.80 & $1.90-38.5$ \\
\hline Norell, 1986 & 99 & $\begin{array}{l}\text { Newly diagnosed } \\
\text { patients, Sweden }\end{array}$ & 301 & Community & $\mathrm{SR}$ & $>5$ & 4.0 & Age, sex, residence & 2.40 & $0.60-9.70$ \\
\hline Frye, 2000 & 116 & $\begin{array}{l}\text { Patients, New } \\
\text { Zealand }\end{array}$ & 232 & Hospital patients & $M R$ & $>1$ & & Age, sex & 2.75 & $0.81-10.2$ \\
\hline Farrow, 1990 & 148 & $\begin{array}{l}\text { Patients in cancer } \\
\text { registry US }\end{array}$ & 188 & Community & $\mathrm{P}$ & $>3$ & 7.1 & $\begin{array}{l}\text { Age, smoking, } \\
\text { education }\end{array}$ & $\begin{array}{l}1.75 \\
6.70\end{array}$ & $\begin{array}{l}0.46-7.09 \\
1.80-24.9\end{array}$ \\
\hline Jain, |991 & 249 & $\begin{array}{l}\text { Newly diagnosed } \\
\text { patients, Canada }\end{array}$ & 505 & Community & $\mathrm{SR}, \mathrm{P}$ & $5-10$ & 3.8 & $\begin{array}{l}\text { Age, sex, smoking, } \\
\text { energy and fiber } \\
\text { intake }\end{array}$ & 2.14 & $0.75-6.17$ \\
\hline Lin, 1981 & 109 & $\begin{array}{l}\text { Hospitalised } \\
\text { patients, US }\end{array}$ & 109 & Hospital patients & $\mathrm{SR}$ & $>1$ & 7.4 & $\begin{array}{l}\text { Age, sex, race, } \\
\text { marital status, } \\
\text { hospital }\end{array}$ & 0.78 & $0.28-2.09$ \\
\hline \multirow[t]{2}{*}{$\begin{array}{l}\text { Bueno de Mesquita, } \\
1992\end{array}$} & 176 & $\begin{array}{l}\text { Patients, } \\
\text { Netherlands }\end{array}$ & 487 & Community & $S R, P$ & $>1$ & $6.4 M$ & $\begin{array}{l}\text { Age, proxy, } \\
\text { smoking }\end{array}$ & 0.73 & $0.27-2.00$ \\
\hline & & & & & & & $7.3 \mathrm{~F}$ & & 0.93 & $0.35-2.50$ \\
\hline Ekoe, 1992 & 179 & Patients, Quebec & 239 & Community & $\mathrm{SR}$ & $>1$ & NA & $\begin{array}{l}\text { Age, sex, smoking, } \\
\text { education }\end{array}$ & 2.52 & $|.04-6.1|$ \\
\hline Kalapothaki, 1993 & |8| & $\begin{array}{l}\text { Hospitalised } \\
\text { patients, Greece }\end{array}$ & 362 & $\begin{array}{l}\text { Hospitalised } \\
\text { patients }\end{array}$ & $\mathrm{SR}$ & $>10$ & 5.0 & Age, sex, hospital & 3.60 & $1.80-7.10$ \\
\hline Silverman, 200I & 526 & $\begin{array}{l}\text { Hospitalised } \\
\text { patients, US }\end{array}$ & 2153 & Community & $\mathrm{SR}, \mathrm{P}$ & $2-4$ & NA & $\begin{array}{l}\text { Age, sex, race, area, } \\
\text { smoking, alcohol, } \\
\text { BMI }\end{array}$ & 1.40 & $0.70-2.40$ \\
\hline Gold, 1985 & 201 & $\begin{array}{l}\text { Newly diagnosed } \\
\text { patients, US }\end{array}$ & 402 & $\begin{array}{l}\text { Hospitalised } \\
\text { patients }\end{array}$ & $\mathrm{SR}, \mathrm{P}$ & $>2$ & 10.0 & $\begin{array}{l}\text { Age, sex, race, } \\
\text { hospital }\end{array}$ & 0.63 & $0.34-1.15$ \\
\hline \multirow[t]{2}{*}{ La Vecchia, 1994} & 362 & $\begin{array}{l}\text { Hospitalised } \\
\text { patients, Italy }\end{array}$ & 1089 & $\begin{array}{l}\text { Hospitalised } \\
\text { patients }\end{array}$ & $\mathrm{SR}$ & $>1$ & $14.4 M$ & $\begin{array}{l}\text { Age, sex, education, } \\
\text { BMl }\end{array}$ & 2.60 & $1.80-4.80$ \\
\hline & & & & & & & $9.8 \mathrm{~F}$ & & 1.40 & $0.80-2.50$ \\
\hline Bonelli, 2003 & 202 & $\begin{array}{l}\text { Hospitalised } \\
\text { patients, Italy }\end{array}$ & 406 & $\begin{array}{l}\text { Hospitalised } \\
\text { patients }\end{array}$ & $\mathrm{SR}$ & $>1$ & 18.3 & $\begin{array}{l}\text { Age, sex, centre, } \\
\text { education, } \\
\text { occupation, } \\
\text { tobacco, alcohol }\end{array}$ & 2.80 & $1.63-4.76$ \\
\hline Lee, 1996 & 282 & $\begin{array}{l}\text { Hospitalised } \\
\text { patients, Taipei }\end{array}$ & 282 & Hospital & $\mathrm{SR}$ & $>1$ & 28.7 & $\begin{array}{l}\text { Age, sex, smoking, } \\
\text { alcohol }\end{array}$ & 2.84 & $1.80-4.52$ \\
\hline Gullo, 1994 & 720 & $\begin{array}{l}\text { Hospitalised } \\
\text { patients, Italy }\end{array}$ & 720 & $\begin{array}{l}\text { Hospitalised } \\
\text { patients }\end{array}$ & $\mathrm{SR}, \mathrm{MR}$ & $>1$ & 13.6 & $\begin{array}{l}\text { Age, social class, } \\
\text { region, hospital }\end{array}$ & 1.80 & $1.30-2.50$ \\
\hline O'Mara, 1985 & 93 & $\begin{array}{l}\text { Hospitalised } \\
\text { patients, US }\end{array}$ & NA & $\begin{array}{l}\text { Hospitalised } \\
\text { patients }\end{array}$ & $\mathrm{SR}$ & NA & 7.6 & Age & 2.40 & $1.80-3.50$ \\
\hline
\end{tabular}

$\mathrm{PC}=$ pancreatic cancer; $\mathrm{SR}=$ self-reported diabetes; $\mathrm{MR}=$ medical record of diabetes; $\mathrm{P}=$ proxy provided information on diabetes status; $\mathrm{NA}=$ data not available 
Table 2 Cohort and nested case-control studies of diabetes and pancreatic cancer

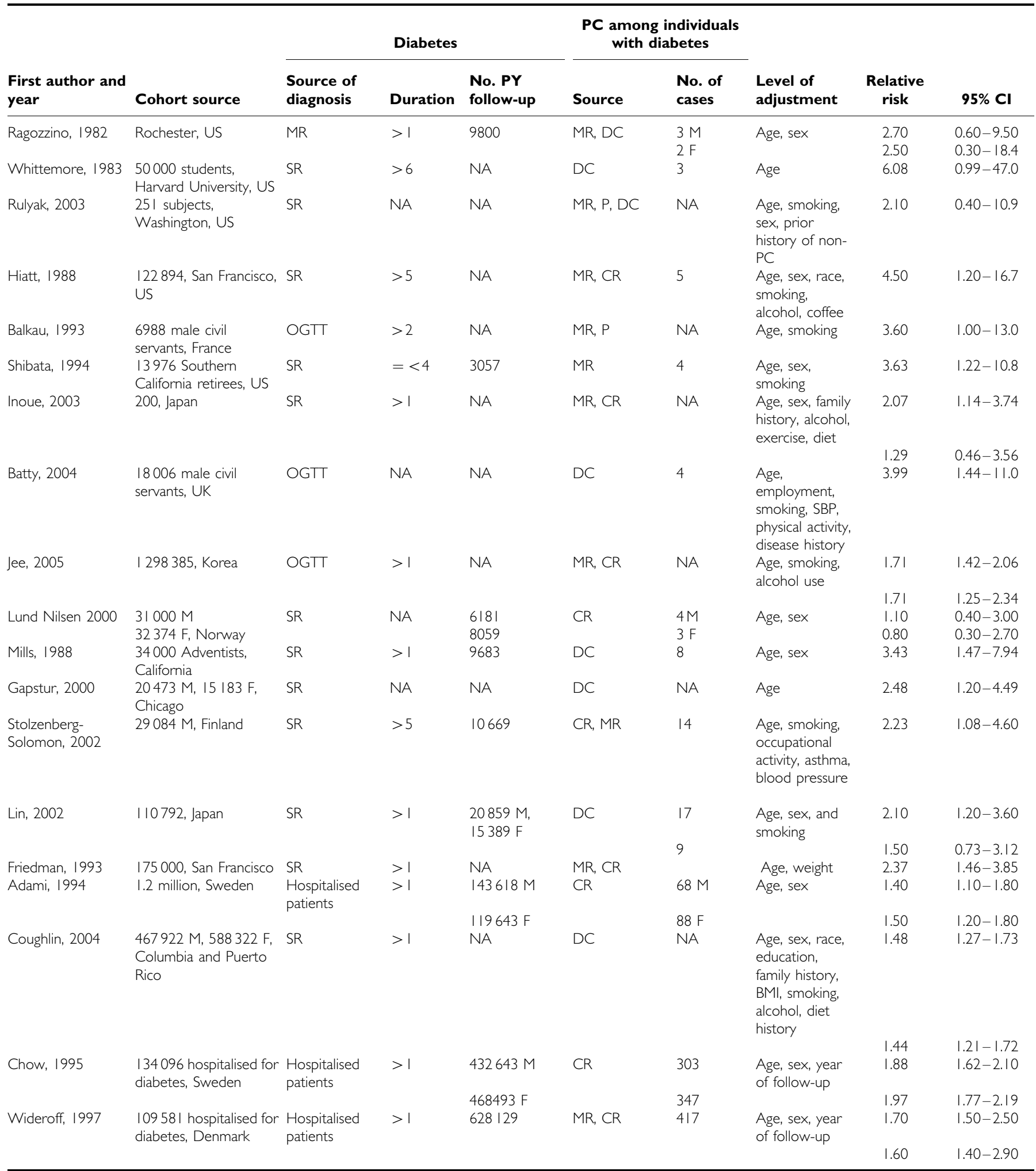

$\mathrm{PC}=$ pancreatic cancer; $\mathrm{MR}=$ medical record of diabetes; $\mathrm{SR}=$ self-reported diabetes; $\mathrm{OGTT}=$ oral glucose tolerance test; $\mathrm{P}=$ proxy provided information on diabetes status; $N A=$ data not available; $D C=$ death certificate; $C R=$ case-record form; $M=$ male; $F=$ female.

heterogeneity within both the case-control $(P=0.002)$ and the cohort studies $(P=0.05)$ that was that was not explained by differences in strength of effect between men and women, adjustment for cigarette smoking or the method of diagnosis of diabetes (Figure 3). Furthermore, there was no difference in the summary RR from those studies that had adjusted for variables other than age and sex compared to those studies that were unable to adjust for other potential confounders ( $R R \quad 1.85$ vs 1.80; 
Type-II diabetes and pancreatic cancer: a meta-analysis

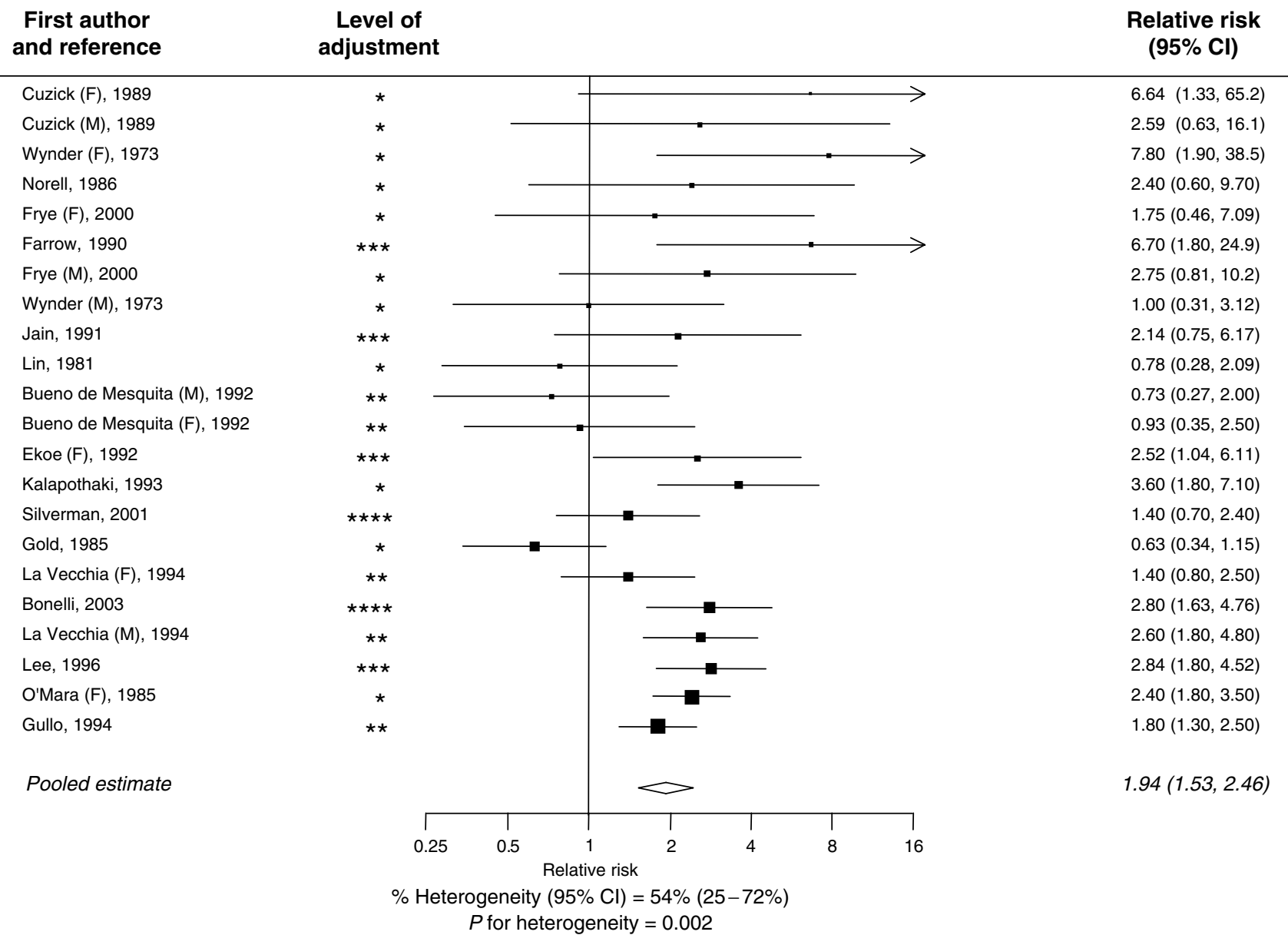

Figure I Relationship between type-II diabetes and risk of pancreatic cancer in case-control studies. Black square=point estimate (with area proportional to statistical 'information', based on inverse of variance of the OR provided by each study) and horizontal line $=95 \% \mathrm{Cl}$ for observed effect in

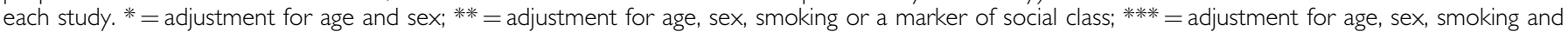
social class; $* * * * * *$ adjustment for age, sex, smoking, social class and dietary variables.

$P=0.78)$. There was some evidence to suggest that smaller studies tended to report higher RRs compared with larger studies $(P=0.02)$. In addition, the summary estimate from studies that were published before 2000 was significantly higher than those studies published after this date: 1.90 (95\% CI 1.67-2.15) vs 1.62 (95\% CI 1.48-1.78): $P=0.046$.

Nine studies had reported mutually exclusive categories for the duration of diabetes that were broadly similar across the studies: $<4$ years, 5-9 years and $>10$ years. Individuals who had the shortest history of diabetes ( $<4$ years) had more than a $50 \%$ greater risk of developing pancreatic cancer than individuals who had diabetes for between 5 and 10 years or for more than 10 years (OR 2.1 95\% CI 1.9-2.3 vs OR 1.5 95\% CI 1.3-1.8; Figure 4).

\section{DISCUSSION}

The findings from this review suggest that earlier reports of a more than two-fold excess risk of pancreatic cancer among individuals with type-II diabetes are likely to have overestimated the strength of the association (Ragozzino et al, 1982; Friedman and Van Den Eeden, 1993; Everhart and Wright, 1995). Although the current data suggest an $80 \%$ greater risk of pancreatic cancer among individuals with type-II diabetes, even this may be an exaggeration of the true strength of the relationship, as it does not consider the considerable potential for reverse causality.
The RR of pancreatic cancer was demonstrated to be negatively associated with the duration of diabetes. Among individuals with a long history of diabetes ( $>5$ years), the excess RR of pancreatic cancer was about $50 \%$ lower than in individuals for whom the duration of diabetes was shorter (RR 1.5 vs $2.1 ; P=0.005$ ). This supports the hypothesis that, in some cases, diabetes may be an early manifestation of the tumour, as otherwise the RR would be expected to increase, rather than decrease, with duration of diabetes. In an earlier review similar RRs of pancreatic cancer by duration of diabetes were reported (Everhart and Wright, 1995) but, the categories for duration of diabetes, unlike in the current meta-analysis, were not mutually exclusive (i.e. $>5$ years diabetes duration was a subset of the $>1$ year group) and therefore, the RR for the $>1$ year duration of diabetes was likely to have been diluted by the inclusion of cases with a longer history of diabetes (and hence a smaller RR).

Evidence from the literature further supports the hypothesis that pancreatic cancer can induce a diabetic state. First, several studies have shown that the risk of pancreatic cancer among individuals with diabetes is lessened after exclusion of those with less that 1 year of diabetes, indicating that a component of the RR associated with diabetes is explained by individuals who are diagnosed with the malignancy within a short period of being diagnosed with diabetes (Ragozzino et al, 1982; Cuzick and Babiker, 1989). Second, in studies among individuals with pancreatic cancer who underwent tumour resection, insulin sensitivity and diabetes status 


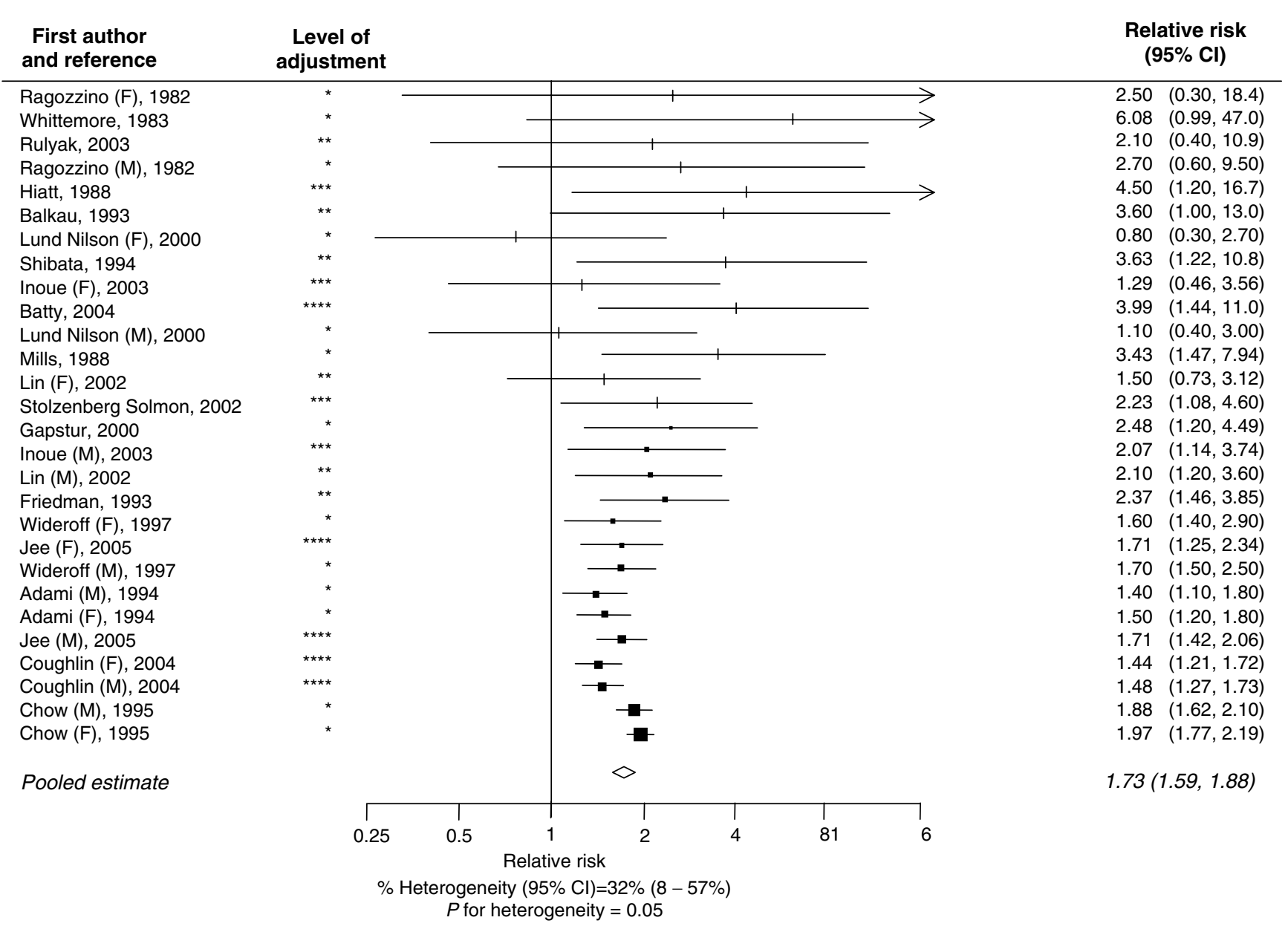

Figure 2 Relationship between type-Il diabetes and risk of pancreatic cancer in cohort studies (conventions as in Figure I).

were reported as showing substantial improvement 3 months after surgery (Permert et al, 1993). And third, molecular studies of sera from pancreatic cancer patients have identified peptides that are suggested to be diabetogenic (Wang et al, 2003).

Although the above arguments support the idea of reverse causality, the finding of a $50 \%$ increased RR of pancreatic cancer among individuals with chronic diabetes ( $>5$ years) supports a modest causal relationship between diabetes and pancreatic cancer. This is true especially when considering that in individuals with a long history of diabetes ( $>5$ years), it is unlikely that a malignancy that has a particularly low 1-year survival rate (fewer than $20 \%$ of individuals are alive at 1-year following diagnosis) could induce diabetes many years prior to its diagnosis. In addition, the presence of a graded dose-response association between fasting glucose and pancreatic cancer, reported by some large prospective studies, supports a causal relationship (Batty et al, 2004; Jee et al, 2005).

Inherent in any review process of published studies is the possibility of publication bias that may have resulted in an overestimate of the size of any association between two variables. There was some evidence to suggest that there was some publication bias such that the smaller studies were more likely to report a positive association between diabetes and pancreatic cancer. However, the exclusion of any small negative studies is unlikely to have materially altered the overall summary estimate. Confounding is also likely to have been present since diabetes and pancreatic cancer share several risk factors such as cigarette smoking and obesity. However, adjustment for a wide range of potential confounders only marginally attenuated the relationship between diabetes and pancreatic cancer. It is also possible that the use of aspirin and other nonsteroidal anti-inflammatory drugs (NSAIDS) may have been a potential confounder. For example, in a prospective follow-up study of over 28000 postmenopausal women, women who reported using aspirin and other NSAIDS had a significantly lower RR of pancreatic cancer compared to non-users (RR 0.57 95\% CI 0.36-0.90) (Anderson et al, 2002). In recent years, individuals with diabetes have been more likely to receive advice to take aspirin than people without diabetes in order to lower the risk of cardiovascular disease (CVD). For example, in the UK Prospective Diabetes Study, it was reported that between $1996 / 1997$ and $2000 / 2001$, aspirin use in patients without preexisting CVD increased from 17 to $31 \%(P<0.0001)$ (Cull et al, 2004). Aspirin has been reported to reduce the risk of several types of cancer (Garcia Rodriguez and Huerta-Alvarez, 1998; Thun et al, 1993); hence, the association between diabetes and pancreatic cancer may have been attenuated by aspirin use and indeed in studies published before 1995, the RR was significantly higher than in those published after this date (RR 2.3 vs 1.8).

Furthermore, most studies included in this review did not differentiate between Type-I and Type-II diabetes, which may have slightly underestimated the overall association, since it has been reported that Type-1 diabetes is not associated with pancreatic cancer (Zendehdel et al, 2003). The literature, however, regarding cancer mortality among individuals with type 1 diabetes, is limited by small sample size and short length of follow-up (Mihara et al, 1986; Martinenghi et al, 1997) and therefore do not preclude a 
Type-II diabetes and pancreatic cancer: a meta-analysis

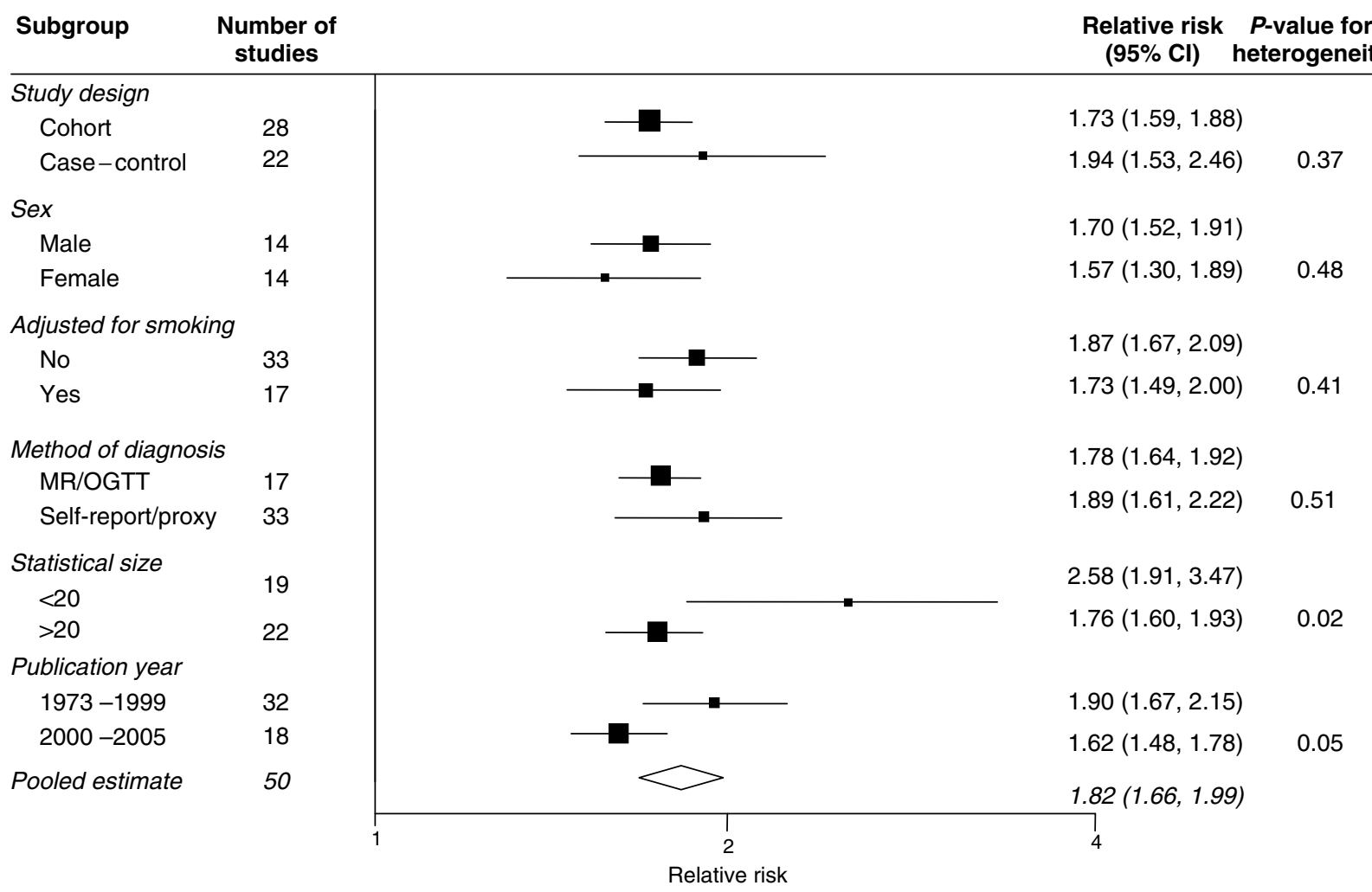

Figure 3 Sensitivity analyses (conventions as in Figure I). MR = medical record; OGTT = oral glucose tolerance test; self-report= self-reported diabetes; proxy $=$ diabetes status given by proxy.

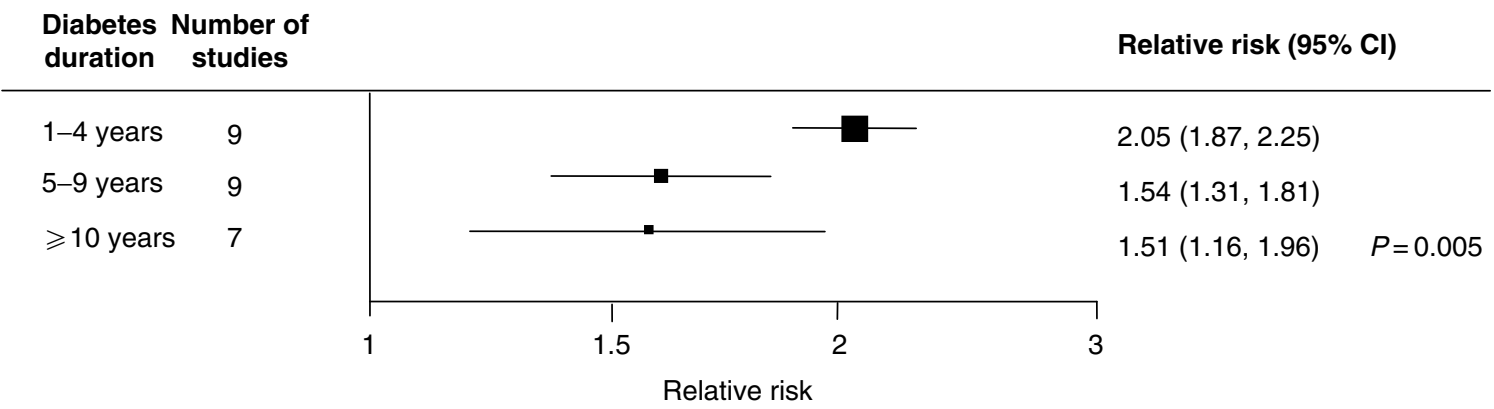

Figure 4 Relative risk of pancreatic cancer by duration of diabetes (conventions as in Figure I).

possible association. However, it is likely that the substantial majority of individuals with diabetes included in these studies had type-II diabetes, since this is by far the most common form particularly in older individuals. Additional limitations of this review include the reliance, in the large majority of studies, on selfreported diabetes and the potential for misclassification on death certificates of site-specific cancers, although the sensitivity analyses did not show any difference in the risk between those studies that used self-reported diabetes compared with those that diagnosed diabetes either through medical records or by an oral glucose tolerance test.

To date, only cigarette smoking, and possibly obesity, has been identified as being causally associated with pancreatic cancer. The evidence from this review indicates that type-II diabetes is likely to be a third modifiable risk factor (Knowler et al, 2002; Davey Smith et $a l, 2005)$ and unless the increasing worldwide prevalence of all three risk factors is halted, the incidence of pancreatic cancer will rise substantially within the next couple of decades.

\section{REFERENCES}

Adami H-O, McLaughlin J, Ekbom A (1994) Cancer risk in patients with diabetes mellitus. Cancer Causes Control 2: 307-314

Anderson KE, Johnson TW, Lazovich D, Folsom AR (2002) Association between nonsteroidal anti-inflammatory drug use and the incidence of pancreatic cancer. J Nat Cancer Inst 94: 1168-1171
Baghurst PA, McMichael AJ, Slavotinek AH, Baghurst KI, Boyle P, Walker AM (1991) A case-control study of diet and cancer of the pancreas. Am J Epidemiol 134: $167-179$

Balkau B, Barrett-Connor E, Eschwege E, Richard J-L, Claude J-R, Ducimetiere P (1993) Diabetes and pancreatic cancer. Diab Metab 19: 458-462 
Batty GD, Shipley MJ, Marmot M, Smith GD (2004) Diabetes status and post-load plasma glucose concentration in relation to site-specific cancer mortality: findings from the original Whitehall study. Cancer Causes Control 15: 873-881

Berrington de Gonzalez A, Sweetland S, Spencer E (2003) A metaanalysis of obesity and the risk of pancreatic cancer. $\mathrm{Br} J$ Cancer 89: 519-523

Bonelli L, Aste H, Bovo P, Cavallini G, Felder M, Gusmaroli R, Morandini E, Ravelli P, Briglia R, Lombardo L, De Micheli A, Pugliese V (2003) Exocrine pancreatic cancer, cigarette smoking, and diabetes mellitus: a case-control study in northern Italy. Pancreas 27: 143-149

Bueno de Mesquita HB, Maisonneuve P, Moerman CJ, Walker AM (1992) Aspects of medical history and exocrine carcinoma of the pancreas: a population-based case-control study in the Netherlands. Int J Cancer 52: $17-23$

Calle EE, Murphy TK, Rodriguez C, Thun MJ, Heath WC (1998) Diabetes mellitus and pancreatic cancer mortality in a prospective cohort of US adults. Canc Causes Contr 9: 403-410

Chow WH, Gridley G, Nyren O, Linet MS, Ekbom A, Fraumeni Jr JF, Adami HO (1995) Risk of pancreatic cancer following diabetes mellitus: a nationwide cohort study in Sweden. J Nat Canc Inst 87: 930-931

Coughlin SS, Calle EE, Patel AV, Thun MJ (2000) Predictors of pancreatic cancer mortality among a large cohort of United States adults. Cancer Causes Control 11: 915-923

Coughlin SS, Calle EE, Teras LR, Petrelli J, Thun MJ (2004) Diabetes mellitus as a predictor of cancer mortality in a large cohort of US adults. Am J Epidemiol 159: 1160 - 1167

Cull CA, Neil HA, Holman RR (2004) Changing aspirin use in patients with Type 2 diabetes in the UKPDS. Diab Med 21: 1368-1371

Cuzick J, Babiker AG (1989) Pancreatic cancer, alcohol, diabetes mellitus and gall-bladder disease. Int $J$ Cancer 43: 415-421

Davey Smith G, Bracha Y, Svendsen KH, Neaton JD, Haffner SM, Kuller LH (2005) Multiple Risk Factor Intervention Trial Research Group. Incidence of type 2 diabetes in the randomized multiple risk factor intervention trial. Ann Intern Med 142: 313-322

Davey Smith G, Egger M, Shipley MJ, Marmot MG (1992) Post-challenge glucose concentration, impaired glucose tolerance, diabetes and cancer mortality in men. Am J Epidemiol 136: $1110-1114$

Doll R, Peto R (1976) Mortality in relation to smoking: 20 years observation on male British doctors. Br Med J 2: $1525-1536$

Ekoe JM, Ghadirian P, Simard A, Baillargeon J, Perret C (1992) Diabete sucre et cancer du pancreas: une etude cas-temoins dans le grand Montreal, Quebec, Canada. Rev Epidemiol Sante Publ 40: 447-453

Everhart J, Wright D (1995) Diabetes mellitus as a risk factor for pancreatic cancer: a meta-analysis. JAMA 273: 1605-1609

Farrow DC, Davis S (1990) Risk of pancreatic cancer in relation to medical history and the use of tobacco, alcohol and coffee. Int J Cancer 45: $816-820$

Friedman GD, Van Den Eeden SK (1993) Risk factors for pancreatic cancer: an exploratory study. Int J Epidemiol 22: 30-37

Frye JN, Inder WJ, Dobbs BR, Frizelle FA (2000) Pancreatic cancer and diabetes: is there a relationship? A case-controlled study. Aust NZ J Surg 70: $722-724$

Gapstur SM, Gann PH, Lowe W, Liu K, Colangelo L, Dyer A (2000) Abnormal glucose metabolism and pancreatic cancer mortality. JAMA 283: $2552-2558$

Garcia Rodriguez LA, Huerta-Alvarez C (1998 Reduced risk of colorectal cancer among long-term users of aspirin and nonaspirin nonsteroidal anti-inflammatory drugs. Epidemiology 12: 88-93

Gold EB, Gordis L, Diener MD (1985) Diet and other risk factors for cancer of the pancreas. Cancer 55: $460-467$

Gullo L, Pezzilli R, Morselli-Labate AM, for the Italian Pancreatic Cancer Study Group (1994) Diabetes and the risk of pancreatic cancer. $N$ Engl $J$ Med 331: $81-84$

Hiatt RA, Klatsky AL, Armstrong MA (1988) Pancreatic cancer, blood glucose and beverage consumption. Int J Cancer 41: 794-797

Inoue $\mathrm{M}$, Tajima $\mathrm{K}$, Takezaki $\mathrm{T}$, Hamajima $\mathrm{N}$, Hirose $\mathrm{K}$, Ito $\mathrm{H}$, Tominaga $\mathrm{S}$ (2003) Epidemiology of pancreatic cancer in Japan: a nested case-control study from the Hospital-based Epidemiologic Research Program at Aichi Cancer Center (HERPACC). Inter J Epidemiol 32: $257-262$

Jain M, Howe GR, St Loluis P, Miller AB (1991) Coffee and alcohol as determinants of risk of pancreas cancer: a case-control study from Toronto. Int J Cancer 47: 384-389
Jee SH, Ohrr H, Sull JW, Yun JE, Ji M, Samet JM (2005) Fasting serum glucose level and cancer risk in Korean men and women. JAMA 293: $194-202$

Kalapothaki V, Tzonou A, Hsieh C-C, Toupadaki N, Karakatsani A, Trichopoulos D (1993) Tobacco, ethanol, coffee, pancreatitis, diabetes mellitus, and cholelithiasis as risk factors for pancreatic carcinoma. Cancer Causes Control 4: 375-382

Kessler II (1970) Cancer mortality among diabetics. J Nat Cancer Inst 44: $673-686$

Knowler WC, Barrett-Connor E, Fowler SE, Hamman RF, Lachin JM, Walker EA, Nathan DM, Diabetes Prevention Program Research Group (2002) Reduction in the incidence of type 2 diabetes with lifestyle intervention or metformin. $N$ Engl J Med 346: 393-403

La Vecchia C, Negri E, D’Avanzo B, Ferraroni M, Gramenzi A, Savoldelli R, Boyle P, Franceschi S (1990) Medical history, diet and pancreatic cancer. Oncology 47: 463-466

La Vecchia C, Negri E, Franceschi S, D’Auanzo B, Boyle P (1994) A casecontrol study of diabetes mellitus and cancer risk. Br J Cancer 70: $950-953$

Lee CT, Chang FY, Lee SD (1996) Risk factors for pancreatic cancer in orientals. J Gastroenterol Hepatol 11: 491-495

Lin RS, Kessler II (1981) A multifactorial model for pancreatic cancer in man: epidemiologic evidence. JAMA 245: 147-152

Lin Y, Tamakoshi A, Kawamura T, Inaba Y, Kikuchi S, Motohashi Y, Kurosawa M, Ohno Y (2002) Risk of pancreatic cancer in relation to alcohol drinking, coffee consumption and medical history: findings from the Japan collaborative cohort study for evaluation of cancer risk. Inter J Cancer 99: $742-746$

Lund Nilsen TI, Johnsen R, Vatten LJ (2000) Socio-economic and lifestyle factors associated with the risk of prostate cancer. Br J Cancer 82: $1358-1363$

Martinenghi S, Dell'Antonio G, Secchi A, Di Carlo V, Pozza G (1997) Cancer arising after pancreas and/or kidney transplantation in a series of 99 diabetic patients. Diabetes Care 20: 272-275

Mihara T, Oohashi H, Hirata Y (1986) Mortality of Japanese diabetics in a seven-year follow-up study. Diabetes Res Clin Pract 2: 139-144

Mills PK, Beeson WL, Abbey DE, Fraser GE, Phillips RL (1988) Dietary habits and past medical history as related to fatal pancreas cancer risk among Adventists. Cancer 61: 2578-2585

Norell S, Ahlbom A, Erwald R (1986) Diabetes, gall stone disease, and pancreatic cancer. $B r$ J Cancer 54: 377-378

O’Mara BA, Byers T, Schoenfeld E (1985) Diabetes mellitus and cancer risk: a multisite case - control study. J Chron Dis 38: 435-441

Parkin DM, Bray F, Ferlay J, Pisani P (2002) Global cancer statistics, 2002. CA Cancer J Clin 55: 74-108

Permert J, Adrain TE, Jacobssen P, Jorfelt L, Fruin AB, Larsson J (1993) Is profound peripheral insulin resistance in patients with pancreatic cancer caused by a tumor-associated factor? Am J Surg 165: 61-67

Ragozzino M, Melton LJ, Chu C-P, Palumbo PJ (1982) Subsequent cancer risk in the incidence cohort of Rochester, Minnesota, residents with diabetes mellitus. J Chron Dis 35: 13-19

Rulyak SJ, Lowenfels AB, Maisonneuve P, Brentnall TA (2003) Risk factors for the development of pancreatic cancer in familial pancreatic cancer kindreds. Gastroenterology 124: 1292 - 1299

Shibata A, Mack TM, Paganini-Hill A, Ross RK, Henderson BE (1994) A prospective study of pancreatic cancer in the elderly. Int J Cancer 58: $46-49$

Silverman DT (2001) Risk factors for pancreatic cancer: a case-control study based on direct interviews. Teratogen Carcinogen Mutagen 21: $7-25$

Silverman DT, Schiffman M, Everhart J, Goldstein A, Lillemoe KD, Swanson GM, Schwartz AG, Brown LM, Greenberg RS, Schoenberg JB, Pottern LM, Hoover RN, Fraumeni Jr JF (1999) Diabetes mellitus, other medical conditions and familial history of cancer as risk factors for pancreatic cancer. Br J Cancer 80: 1830 - 1837

Stolzenberg-Solomon RZ, Pietinen P, Taylor PR, Virtamo J, Albanes D (2002) Prospective study of diet and pancreatic cancer in male smokers. Am J Epidemiol 155: 783-792

Thun MJ, Namboodiri MM, Calle EE (1993) Aspirin use and risk of fatal cancer. Cancer Res 53: 1322-1327

Wang F, Herrington M, Larsson J, Permert J (2003) The relationship between diabetes and pancreatic cancer. Mol Cancer 2: 4-8

Whittemore AS, Paffenbarger RS, Anderson K, Halpern J (1983) Early precursors of pancreatic cancer in college men. J Chron Dis 36: $251-256$ 
Type-II diabetes and pancreatic cancer: a meta-analysis

R Huxley et al

Wideroff L, Gridley G, Mellemkjaer L, Chow WH, Linet M, Keehn S, BorchJohnsen K, Olsen JH (1997) Cancer incidence in a population-based cohort of patients hospitalized with diabetes mellitus in Denmark. J Natl Cancer Inst 89: 1360 - 1365

Woodward M (2005) Epidemiology: Study Design and Data Analysis 2nd edn Boca Raton: Chapman and Hall/CRC
Wynder EL, Mabuchi K, Maruchi N, Fortner JG (1973) Epidemiology of cancer of the pancreas. J Natl Cancer Inst 50: 645-667

Zendehdel K, Nyren O, Ostenson C-G, Adami H-O, Ekbom A, Ye W (2003) Cancer incidence in patients with type 1 diabetes mellitus: a population-based cohort study in Sweden. J Nat Canc Inst 95: $1797-1800$ 